\title{
我国长江流域梅雨变动与南极冰雪 状况的可能联系
}

\author{
符淙 坟 \\ （中国科学院大气物理研究所）
}

梅雨是我国江淮流域的重要天气气候现象. 梅雨量的多少、梅雨期的长短以及入梅出梅 时间的早晚对这一地区的农业生产有显著的影响. 关于中国的梅雨已作过大量的研究, 但多 限于北半球大气环流的分析 ${ }^{[1]}$. 吕昫曾讨论过太平洋海温与梅雨的关系 ${ }^{[2]}$. 本文利用近十年 卫星观测的南极海冰资料和本世纪初以来南极地区的积雪量资料,发现了一个有意义的事实: 南极地区的冰雪状况与长江流域出梅时间的早晚有密切的关系. 并且通过一组典型例子的分 析揭示, 南极海冰状况的变动可以使西太平洋地区平均经圈环流发生明显的南北位移, 从而带 来行星风系和气候带的移动,产生相隔近百个纬距的遥远相关.

本文所用梅雨资料取自中央气象台长期科. 它是根据长江中下游地区的上海、南京、芜 湖、汉口和九江五个站的降水量、温度和太平洋副热带高压的特点综合确定的. 所用南极积雪 量资料取自文献 [3],南极海冰资料取自文献 [4]。

\section{一、南极冰雪状况与梅雨的关系}

根据近四十年资料的统计, 梅雨的变动与出梅日期之间关系密切。一般来说, 出梅早, 梅 期就短, 梅雨量就少; 出梅晚, 梅期长, 梅雨量多. 因此, 这里用出梅日期来表征梅雨的变动. 它反映的大气环流特点是季节性跃变的早晚和行星锋区位置的南北摆动.

图 1 给出 1900-1970 年南极积雪量和长江流域出梅日期的十年滑动平均曲线. 显见, 在 长期变化中存在着一种有趣的关系: 南极积雪量多, 长江流域出梅早; 南极积雪量少, 长江流 域出梅晚. 例如, 1902-1920，1940-1956 年间，南极积雪量少(约6克/厘米 2 年), 相应长 江流域出梅期偏晚 (7 月 14 日), 其中 1940-1956 年为近四十年来典型丰梅雨时期. 而 1921一 1938 年, 1957-1968 年, 南极积雪量增多 (约 8 克/厘米 ${ }^{2}$ 年), 相应长江流域出梅偏早 (6月

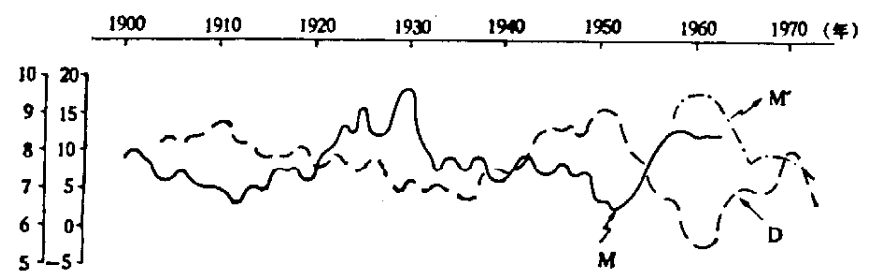

图 11900-1970 年南极积雪量 (M) 和长江流域出梅期 (D) 的十年滑动平均变化曲线 （左侧第一坐标为 $\mathrm{M}$, 单位为克/厘米 ${ }^{2}$ 年; 第二坐标为 $\mathrm{D}$, 采用编码, 6 月 30 日为 -1 ,

7 月 1 日为 +1, 其余类推; $\mathrm{M}^{\prime}$ 为由温度推算之积雪)

本文 1980 年 7 月 23 日收到. 


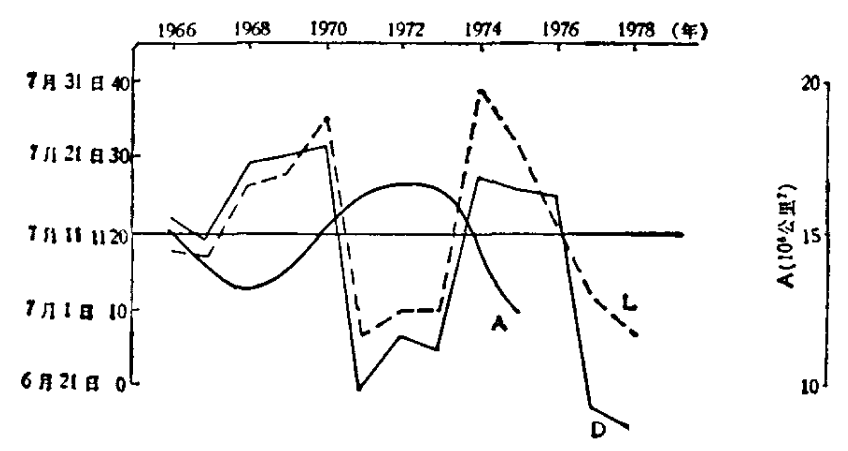

图 2 1966-1975 年南极海冰面积 (A)、长江流域出梅期 (D) 和梅雨期长度 (L) (天数)的年际变化曲线

下旬一 6 月底). 计算两组曲线的相关系数为 -0.69 . 这一事实表明, 本世纪以来长江流域梅 雨的长期变化趋势可能与南极积雪状况变化有关.

为进一步考察上述联系,图 2 给出 1966-1975 年南极海冰面积与长江流域出梅期和梅雨 期长度的逐年变化曲线. 此处给出的是上年十一月末的海冰面积, 可代表全年平均状况. 由 图 2 可见,南极海冰的影响具有与海温相似的滞后效应. 如上年南极海冰面积缩小, 来年长江 出梅晚,梅期长,反之,海冰面积扩展, 来年出梅就早,梅期短.

由此说明, 南极冰雪状况与梅雨的关系不仅存在于本世纪以来的长期趋势, 而且反映在近 十年卫星资料所揭示的年际变化上. 这种经向距离达近百个纬距的远距离联系是值得注意的 事实,它反映了两半球之间的更大尺度的相互作用.

\section{二、南极冰雪状况与平均经圈环流的南北位移}

为了给上述事实以初步的物理解释, 现选择一对典型例子进行较仔细的分析. 选取的例 子为 1969 年和 1972 年,它们分别是近十年典型的丰梅年和枯梅年. 1969 年, 梅雨量为 2800 毫米,梅雨期 28 天,出梅为 7 月 21 日; 1972 年,梅雨量为 960 毫米, 梅雨期 10 天,出梅为 6 月 29 日. 这两年北半球冬春季冰雪面积大致相当, 都属于多雪年. 夏季赤道太平洋热状况差异 也不大. 但前期南极海冰范围有显著不同, 1969 年处于谷区, 海冰面积小, 1972 年则处于峰 区附近, 海冰面积大. 因此, 可以认为, 除了本半球和热带的作用外, 南极海冰状况的差异可能 是一个重要因素.

对比分析了这两年夏季北半球、热带、南半球的地面和 500 毫巴环流, 其主要差异为: 在 南极海冰扩展时, 南极洲附近绕极低压带向赤道扩展, 相应南半球副热带高压带减弱北进. 在 对流层中部, 中纬度西风带也向北推进, 从而使赤道缓冲带和北半球赤道辐合带 (下称 ITCZ) 也向北推进, 北半球副热带高压偏北, 季节性北跳提早. 在南极海冰萎缩年份正相反. 其总的 效果是平均经圈环流和行星风系有明显的南北位移. 图 3 给出 1969 年和 1972 年 7 月卫星观 测的西太平洋平均云量廓线和经圈环流图. 在南极海冰萎缩的情况下 (1969年), 整个经圈环 流偏南,南北半球的 Hadley 环流之间的上升分支, 即 ITCZ 的位置在 $10^{\circ} \mathrm{N}$ 附近, 作为 Hadley 环流下沉分支所在的南北半球副热带晴空区分别位于 $20^{\circ} \mathrm{S} 、 25^{\circ} \mathrm{N}$ 附近. 而当南极海冰扩展 时 (1972 年), 经圈环流明显北进, 两半球 Hadley 环流之间的上升分支北移止 $18^{\circ} \mathrm{N}$ 附近, 相 应的副热带下沉分支分别位于 $12^{\circ} \mathrm{S}, 30^{\circ} \mathrm{N}$ 附近. 还要指出, 南半球跨过赤道的 Hadley 环流 

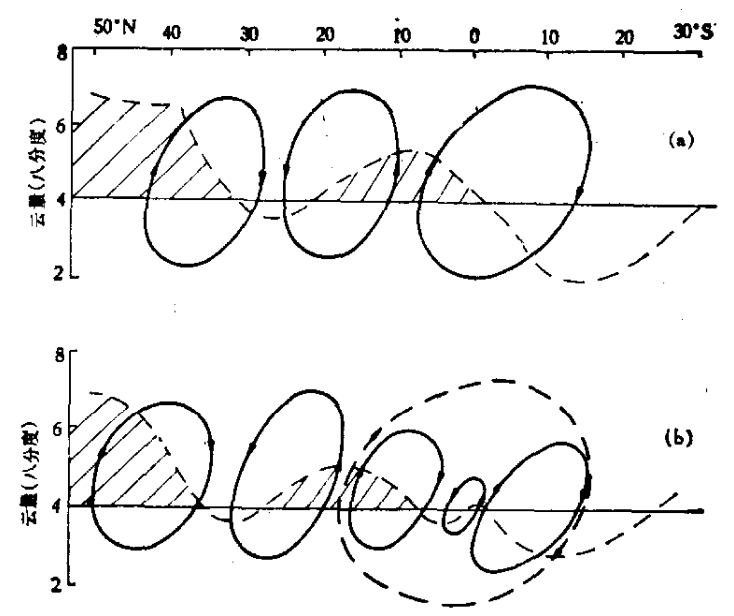

图 3 西太平洋平均云量廓线和经圈环流示意图
(a) 1969 年 7 月;
(b) 1972 年 7 月

可能是由三个较小的环流组成的, 这里可以看到赤道缓冲带和南半球 ITCZ 的痕迹.

进一步分析发现, 正是由于南极热汇的不对称, 即它的冷中心主要偏在东半球 (图略), 上 述影响在西太平洋地区表现得尤其清楚.

\section{三、讨 论}

上述南北半球之间大尺度的经向联系, 可以这样来理解. 我们讨论的梅雨期为北半球夏 季, 此时, 正值南半球的冬季. 此时全球纬圈平均冷热源的分布是这样的: 主要冷源在南极大 陆, 主要热源在赤道以北, 北极为一个次要的冷源. 作为第一近似, 全球平均经圈环流应当是 这样一种形式, 即在北半球热赤道上升的气流主要的一支在高空向南在南极地区下沉, 在低层 折而向北, 且越过赤道, 进人上升分支. 另一支较弱的在高空向北到北极地区下沉, 低层折而 向南,也并入上升分支. 因此, 在这个季节在低层有很强的来自南半球的气流跨过赤道向北. 而南极冰雪状况的变化, 将影响其反照率, 从而改变对太阳辐射的吸收能力, 改变南极热汇的 强度,使经圈环流的南部一环强度和位置发生变化. 实际的经圈环流自然是三圈环流的形式, 但图 3 所反映的经圈环流的明显位移, 正是与南极冰雪变化所产生的南极热汇强度变化有密 切关系的.

因此,在气候尺度问题中, 我们固然仍要注意纬向大尺度波动的影响, 同时还要注意南北 经圈方向的作用, 这种作用与纬圈平均冷热源分布相联系, 直接影响大气运动的能量供给, 因 而可能具有更重要的意义. 本文揭露的由南极冰雪状况变动所引起的经圈环流的位移可能是 其中的一类过程.

\section{参孝 文 献}

[1] 陶诗言, 气象学报, 29(1958), 2:119-134.

[2] 吕昫, 气象学报, 18(1950), 1:1-18.

[ 3 ] Fleteher, J. O., Memorandrum RM-5793-NSF, 1969, 38-49.

[4] Kukla, J. G., Recent Changes in Snow and Ice, in Climatic Change, 1978, 114-129. 